\title{
Recent advances in pediatric gastroenterology, hepatology and nutrition
}

\author{
John A. Barnard
}

Address: The Research Institute at Nationwide Children's Hospital, Division of Gastroenterology, Hepatology and Nutrition, Department of Pediatrics, The Ohio State University College of Medicine, 700 Children's Drive, Columbus, OH 43205

Email: john.barnard@nationwidechildrens.org

Fl000Prime Reports 2013, 5:25 (doi:10.12703/P5-25)

This is an open-access article distributed under the terms of the Creative Commons Attribution-Non Commercial License (http://creativecommons.org/licenses/by-nc/3.0/legalcode), which permits unrestricted use, distribution, and reproduction in any medium, provided the original work is properly cited. You may not use this work for commercial purposes.

The electronic version of this article is the complete one and can be found at: http://fl000.com/prime/reports/m/5/25

\begin{abstract}
Pediatric gastroenterology, hepatology and nutrition are rapidly evolving, exciting and diverse disciplines. Because the field is so expansive, this commentary highlights important trends, rather than narrowly focusing on specific advances. Examples of advances in the highest impact and rapidly moving areas of pediatric gastroenterology are reviewed, including the intestinal microbiome, biomedical genomics, the biology of unique gastrointestinal cell types, and microRNAs (miRNAs).
\end{abstract}

\section{The intestinal microbiome}

Arguably, no single area of research within the broad field of pediatric gastroenterology, hepatology and nutrition has advanced more rapidly than study of the intestinal microbiome. Enabled by advanced microbial genomics and powerful computational biology, our understanding of the microbiome in health and disease has grown at a remarkable pace. We now know that adult humans harbor approximately one hundred-fold more genetic material from microbes than we do from our own genes. And we have learned that, among many other influences on human biology, microbial genetic material contributes in important ways to energy metabolism [1] and development of the human immune system [2]. Indeed, the microbiome contributes a great deal to human phenotypic diversity.

We are just now beginning to probe how age and socioeconomic factors intersect to define the intestinal microbiome. A key advance in this area came in 2012 from the laboratory of Jeffrey Gordon and collaborators [3]. Fecal micoflora from 531 individuals from three continents and markedly different socioeconomic and cultural backgrounds were analyzed by $16 \mathrm{~S}$ ribosomal RNA PCR, followed by deep microbial genomic sequencing. Evolution of the microbiome in each setting was analyzed from birth through adulthood. The investigators found that the phylogenetic composition of bacterial communities in each studied population evolves toward adult composition over the first three years of life, and then stabilizes. Bacterial diversity increases with age in all populations. Interestingly, microbiota of US adults is the least diverse. Functional analysis of microbial genes reveals prominent differences in vitamin and carbohydrate metabolism beginning early in childhood.

This important study highlights many challenges and opportunities in the study of the microbiome. That is, age, geography, diet, and environmental factors are powerful contributors to the composition of an individual's microbiome in health, and likely in disease. Stated differently, there is a dynamic reciprocity between environment and microbiome. These factors must be considered important variables in the design of future studies. A well-known Winston Churchill quote seems especially appropriate to the evolving microbiome field: "Now this is not the end. It is not even the beginning of the end, but it is, perhaps, the end of the beginning".

\section{Genomics}

Next generation genomic technology is revolutionizing clinical medicine, including the field of pediatric gastroenterology, hepatology and nutrition. Over the past 
few years, deep sequencing capabilities have become commercially available, and now exist at many local hospitals. Clearly, the technology has "arrived". What lags behind is our ability to analyze the large volume of genomic data from a single whole exome next generation sequencing run, a daunting challenge that has even been highlighted in the lay press [4].

Terabytes of sequencing data require well-designed, sophisticated filtering strategies to arrive at interpretable clinical information. However, when properly applied to genomic data, compelling conclusions can be reached. Exemplary of this is a recent report of exome sequencing in 8 children with early, severe inflammatory bowel disease phenotypes [5]. The authors' rationale was to focus on early, aggressive phenotypes in young children to provide unique insights into the biology of inflammatory bowel disease. The investigative team from the University of Southampton, UK winnowed 23,000 variants identified by exome sequencing down to 13,000 (by removal of synonymous variants), to 332 (by targeting 169 inflammatory bowel disease susceptibility genes), to a manageable 17 novel variants (by removing splicing, human leukocyte antigen [HLA] and commonly known alleles). When individual research subject profiles highlighted in this manuscript are scrutinized in a clinical context, for example an 11-year old with severe stricturing ileocecal disease who expresses variants in NOD2 (R702W), GSDMB, ZNF365, and IL18RAP, then the potential for a personalized therapeutic approach feels quite realistic.

Other anecdotes support the apparent power of whole exome sequencing for individual patients. In the past two years, reports of complex cases sleuthed and solved by whole exome sequencing have emerged. One of the first [6], reported in 2011, was a 5 year old boy with an unusually aggressive case of inflammatory bowel disease. Using whole exome sequencing, the patient was found to have a mutation in X-linked inhibitor of apoptosis (XIAP), which led to successful management by bone marrow transplantation. The apparent success of this case was widely reported in the lay press, including a Pulitzer Prize winning exposé in the Milwaukee Journal Sentinel [7]. More recently, profoundly ill neonates at Children's Mercy Hospital in Kansas City, carefully chosen using agreedupon clinical criteria, were successfully diagnosed and more appropriately managed as a result of whole exome sequencing [8]. The key was a rapid-analysis algorithm that achieved a molecular genetic diagnosis within 50 hours, an achievement that was also met with a great deal of public interest [9].

Next generation genomics is increasingly incorporated into everyday practice. The economics will be increasingly favorable if deep sequencing is prioritized to prospectively agreed-upon criteria like extreme-phenotype patients with prominent family history whose family members are also available for sequencing.

\section{Unique cells}

Advances in cell biology are permitting an increasingly detailed study of unique cell types of immense importance to gastroenterologists. Two examples from the 2012 literature are highlighted here: the leucine-rich repeatcontaining G-protein coupled receptor (Lgr5) positive crypt base columnar cell and the hepatic stellate cell.

Our understanding of intestinal epithelial stem cell biology has advanced dramatically in recent years, as detailed in a 2012 review [10]. It is increasingly clear that distinct intestinal stem cell types exist. They can be categorized as either rapidly proliferative or quiescent types, each of which has distinctive transcriptional profiles and roles in maintenance of a healthy epithelium [11]. We have now learned enough about these cells that we are able to tease out their complex actions by computational approaches [12].

Lgr5-positive intestinal crypt base columnar cells positioned in contact with Paneth cells are the subject of intense interest as stem cells [10]. In 2012, investigators asked if these cells might form organoids in culture, one measure of their stemness [13]. Indeed, single Lgr5 cells labeled with enhanced green fluorescent protein (EGFP) isolated from disrupted colonic epithelium and placed in a carefully selected milieu of matrix and growth factors were able to form organoids in culture. Moreover, these organoids expressed markers of multiple differentiated intestinal lineages, including goblet cells and enteroendocrine cells. Remarkably, organoids given by intracolonic infusion were able to regenerate colonic epithelial tissues in an in vivo model of colon injury.

Another unique cell of interest to gastroenterologists is the hepatic stellate cell, a non-parenchymal cell that plays a role as a major source of myofibroblasts in the fibrotic response to injury. Much is known about this unique cell, the molecular events leading to its activation, and the consequence of this activation, as summarized in a well written commentary in 2012 [14]. What has been missing from the field is experimental verification of the role of stellate cell depletion in liver injury, a proof of principle that stellate cells are the central figure in regulation of hepatic fibrosis. The Friedman laboratory published such evidence in 2012 using an in vivo model of liver injury [15]. Using a herpes simplex virus thymidine kinase transgene, the investigators used ganciclovir to deplete mouse livers of activated stellate cells. In doing so, they were able to dramatically reduce the hepatic consequences of bile duct 
ligation, carbon tetrachloride toxicity and allyl alcohol toxicity. As hypothesized, hepatic fibrosis was attenuated. An unexpected finding, though, was the reduction in overall liver injury. The mechanism of this finding is yet to be fully understood, but raises the spectra of stellate cell depletion as a potential therapeutic strategy in liver injury and raises exciting questions about the role of stellate cells in liver function beyond their traditional role in fibrogenesis.

Another important question is the reversibility of stellate cell activation. This concept was recently clarified by evidence that activation is indeed reversible, but reverted cells are more amenable to reactivation [16]. This observation has important implications in the setting of chronic or repeated exposures to liver injury. Understanding this phenomenon will also give insight into the design of antifibrotic therapies.

\section{MiRNAs in pediatric gastrointestinal disease}

MiRNAs are 19-25 nucleotide single-stranded RNA molecules that potentially regulate thousands of genes, typically by reducing target gene expression [17]. More than 1200 human miRNAs exist intracellularly or in circulating exosomes. Increasingly, these molecules are now being tested as therapeutic agents or as disease biomarkers in a plethora of pathophysiological situations.

MiRNAs regulate fibrosis in a variety of tissues. Returning to the hepatic stellate cell, we find an interesting example of miRNA regulation of liver fibrosis [18]. MiRNA 19b, which binds the $3^{\prime}$ untranslated region of type II transforming growth factor $\beta$ receptor (TGF $\beta$ RII), is markedly reduced during stellate cell activation. Restoration of miRNA 19b expression in activated stellate cells reduces TGF $\beta$ signaling and expression of downstream targets such as procollagen and $\alpha$ smooth muscle actin, molecules that are associated with hepatic fibrosis. These findings suggest that miRNA $19 \mathrm{~b}$ might be used as a biomarker of fibrosis or perhaps even a novel therapeutic in the prevention of hepatic fibrosis.

Two other miRNAs relevant to pediatric gastrointestinal disease deserve mention. The Joshua Friedman lab at Children's Hospital of Philadelphia found that circulating levels of the miR-200b/429 cluster are elevated in infants with biliary atresia when compared with infants with other cholestatic liver disease [19]. This suggests potential use of these miRNAs as biomarkers of biliary atresia. The Rothenberg laboratory at Cincinnati Children's Hospital Medical Center found 32 up- or down-regulated miRNAs in biopsies of children with eosinophilic esophagitis compared with controls [20]. Moreover, these dysregulated miRNAs reverted to a normal level of expression with corticosteroid treatment. Again, this work suggests the potential value of miRNAs as biomarkers of disease or as a measure of response to therapy.

\section{Future directions}

Molecular, cellular and genetic advances hold the promise of innovative new insights, markers, preventives and therapeutics for pediatric gastrointestinal disease. This review emphasizes that many of these advances are featured in the lay press and are of great public interest. For example, it is likely that we will ultimately develop an armamentarium of specific, targeted preventives and therapeutics related to intestinal microflora. These will be precisely customized to an individual's demography and culture. Genomics will also permit precise and predictive approaches to a multitude of diseases. Most likely these will occur first for single gene defects. We have seen remarkable advances in microRNA biology and these are likely to lead to clinical innovation over the next 5 to 10 years. Finally, the scrutiny of the most intricate features of unique cell types like hepatic stellate cells and intestinal stem cells is beginning to shine a bright light on some of the most fundamental issues in gastroenteric biology and will open prospects for new innovative therapies.

\section{Abbreviations}

EGFP, enhanced green fluorescent protein; HLA, human leukocyte antigen; Lgr5, leucine-rich repeat-containing G-protein coupled receptor; miRNA, microRNAs; TGF, transforming growth factor.

\section{Disclosures}

The author declares that he has no disclosures.

\section{References}

I. Turnbaugh PJ, Gordon Jl: The core gut microbiome, energy balance and obesity. J Physiol (Lond.) 2009, 587:4I53-8.

2. Atarashi K, Tanoue T, Shima T, Imaoka A, Kuwahara T, Momose Y, Cheng G, Yamasaki S, Saito T, Ohba Y, Taniguchi T, Takeda K, Hori S, Ivanov II, Umesaki $Y$, Itoh K, Honda K: Induction of colonic regulatory $T$ cells by indigenous Clostridium species. Science $201 \mathrm{I}, 33 \mathrm{I}: 337-41$.

\section{FlOOOPrime}

RECOMMENDED

3. Yatsunenko T, Rey FE, Manary MJ, Trehan I, Dominguez-Bello MG, Contreras M, Magris M, Hidalgo G, Baldassano RN, Anokhin AP, Heath AC, Warner B, Reeder J, Kuczynski J, Caporaso JG, Lozupone CA, Lauber C, Clemente JC, Knights D, Knight R, Gordon Jl: Human gut microbiome viewed across age and geography. Nature 2012, 486:222-7.

\section{FlOOOPrime}

RECOMMENDED

4. Pollack A: DNA Sequencing Caught in a Deluge of Data. New York Times 201 I.

5. Christodoulou K, Wiskin AE, Gibson J, Tapper W, Willis C, Afzal NA, Upstill-Goddard R, Holloway JW, Simpson MA, Beattie RM, Collins A, Ennis S: Next generation exome sequencing of paediatric 
inflammatory bowel disease patients identifies rare and novel variants in candidate genes. Gut 2012.

\section{FlOOOPrime}

6. Worthey EA, Mayer AN, Syverson GD, Helbling D, Bonacci BB, Decker B, Serpe JM, Dasu T, Tschannen MR, Veith RL, Basehore MJ, Broeckel U, Tomita-Mitchell A, Arca MJ, Casper JT, Margolis DA, Bick DP, Hessner MJ, Routes JM, Verbsky JW, Jacob HJ, Dimmock DP: Making a definitive diagnosis: successful clinical application of whole exome sequencing in a child with intractable inflammatory bowel disease. Genet Med 201 I, I3:255-62.

\section{FIOOOPrime}

\section{RECOMMENDED}

7. Johnson MGK: One in a Billion: A Boy's Life, A Medical Mystery. Milwaukee Journal Sentinel $201 \mathrm{I}$.

8. Saunders CJ, Miller NA, Soden SE, Dinwiddie DL, Noll A, Alnadi NA, Andraws N, Patterson ML, Krivohlavek LA, Fellis J, Humphray S, Saffrey P, Kingsbury Z, Weir JC, Betley J, Grocock RJ, Margulies EH, Farrow EG, Artman M, Safina NP, Petrikin JE, Hall KP, Kingsmore SF: Rapid whole-genome sequencing for genetic disease diagnosis in neonatal intensive care units. Sci Transl Med 2012, 4:154ral 35

\section{FlOOOPrime RECOMMENDED}

9. Kolata G: Infant DNA Tests Speeds Diagnosis of Rare Diseases. New York Times 2012.

10. Barker $\mathrm{N}$, van Oudenaarden A, Clevers $\mathrm{H}$ : Identifying the stem cell of the intestinal crypt: strategies and pitfalls. Cell Stem Cell 2012, I I:452-60.

\section{FlOOOPrime}

\section{RECOMMENDED}

II. Powell AE, Wang Y, Li Y, Poulin EJ, Means AL, Washington MK, Higginbotham JN, Juchheim A, Prasad N, Levy SE, Guo Y, Shyr Y, Aronow BJ, Haigis KM, Franklin JL, Coffey RJ: The pan-ErbB negative regulator $\mathrm{Lrig} I$ is an intestinal stem cell marker that functions as a tumor suppressor. Cell 20I2, I49:|46-58.

\section{FlOOOPrime} RECOMMENDED

12. Itzkovitz S, Blat IC, Jacks T, Clevers H, van Oudenaarden A: Optimality in the development of intestinal crypts. Cell 2012, 148:608-19.

\section{FlOOOPrime}

\section{RECOMMENDED}

13. Yui S, Nakamura T, Sato T, Nemoto Y, Mizutani T, Zheng X, Ichinose S, Nagaishi T, Okamoto R, Tsuchiya K, Clevers H, Watanabe M: Functional engraftment of colon epithelium expanded in vitro from a single adult Lgr5 ${ }^{+}$stem cell. Nat Med 20I2, 18:6I8-23.

FlOOOPrime

14. Friedman SL: Fibrogenic cell reversion underlies fibrosis regression in liver. Proc Natl Acad Sci U S A 2012, 109:9230-I.

\section{FlOOOPrime
RECOMMENDED}

15. Puche JE, Lee YA, Jiao J, Aloman C, Fiel MI, Muñoz U, Kraus T, Lee T, Yee HF, Friedman SL: A novel murine model to deplete hepatic stellate cells uncovers their role in amplifying liver damage in mice. Hepatology 2013, 57:339-50.

\section{FlOOOPrime}

\section{RECOMMENDED}

16. Kisseleva T, Cong M, Paik Y, Scholten D, Jiang C, Benner C Iwaisako K, Moore-Morris T, Scott B, Tsukamoto H, Evans SM, Dillmann W, Glass CK, Brenner DA: Myofibroblasts revert to an inactive phenotype during regression of liver fibrosis. Proc Nat Acad Sci U S A 2012, 109:9448-53.

FIOOOPrime

17. Dai R, Ahmed SA: MicroRNA, a new paradigm for understanding immunoregulation, inflammation, and autoimmune diseases. Transl Res 201 I, I57:163-79.

\section{FlOOOPrime
RECOMMENDED}

18. Lakner AM, Steuerwald NM, Walling TL, Ghosh S, Li T, McKillop IH, Russo MW, Bonkovsky HL, Schrum LW: Inhibitory effects of microRNA $19 \mathrm{~b}$ in hepatic stellate cell-mediated fibrogenesis. Hepatology 2012, 56:300-10.

\section{FlOOOPrime}

\section{RECOMMENDED}

19. Zahm AM, Hand NJ, Boateng LA, Friedman JR: Circulating microRNA is a biomarker of biliary atresia. J Pediatr Gastroenterol Nutr 20I2, 55:366-9.

\section{FlOOPrime}

\section{RECOMMENDED}

20. Lu TX, Sherrill JD, Wen T, Plassard AJ, Besse JA, Abonia JP, Franciosi JP, Putnam PE, Eby M, Martin LJ, Aronow BJ, Rothenberg ME: MicroRNA signature in patients with eosinophilic esophagitis, reversibility with glucocorticoids, and assessment as disease biomarkers. J Allergy Clin Immunol 20I2, I 29:1064-75 e9.

FlOOOPrime

